\title{
Zmiany siły powiązań i zmienności indeksów giełd światowych
}

\section{Streszczenie}

Celem opracowania jest identyfikacja i ocena zmian w kształtowaniu się indeksów giełdowych, a w szczególności zwrócenie uwagi na zmiany siły powiązania indeksów reprezentujących akcje spółek z różnych regionów geograficznych i krajów, a także zmiany zachodzące w zmienności tych indeksów. Przeprowadzona analiza dotyczyła porównania kształtowania się indeksów w czasie, wyodrębnienia podokresów oraz określenia zmian siły powiązań pomiędzy poszczególnymi indeksami na podstawie oszacowanych modeli GARCH. Analizą objęto łącznie 15 indeksów giełdowych w okresie 2.01.2000-31.10.2013. Uzyskane wyniki empiryczne pozwoliły stwierdzić, że mimo okresowych wahań poziomu współczynników korelacji powodowanych sytuacją na giełdzie w zdecydowanej większości współczynniki te wzrastały w długim okresie. W ponad 70\% przypadków nastąpił także wzrost zmienności na analizowanych rynkach.

Słowa kluczowe: indeksy giełdowe, korelacja, zmienność, giełdy światowe.

\section{Wprowadzenie}

W ostatnich kilkunastu latach wyraźnie wzrosły powiązania pomiędzy rynkami giełdowymi wielu krajów. Ich przejawem są m.in. rosnące przepływy kapitału oraz zmiany zachodzące na płaszczyźnie instytucjonalnej (zob. [Mrzygłód 2011]). W przypadku giełd można mówić nawet o całej fali przejęć, fuzji i aliansów strategicznych. Za przykład może posłużyć tutaj powstanie międzynarodowej giełdy Euronext, a następnie NYSE-Euronext, czy giełdy OMX, a następnie Nasdaq-OMX. 
Coraz powszechniej zachodzące procesy liberalizacji działalności gospodarczej, deregulacji rynków oraz rozwoju nowoczesnych technologii przyczyniają się do postępującej globalizacji gospodarki światowej oraz integracji rynków kapitałowych (zob. [Kowalak 2006, Mrzygłód 2011, Friedman i Shachmurove 2005]). Potencjalne korzyści i zagrożenia wynikające z tych procesów stanowią nowe wyzwania dla poszczególnych przedsiębiorstw, rynków i gospodarek. W tym kontekście warto zwrócić uwagę na zmiany zachodzące w sposobie kształtowania się indeksów giełdowych.

Celem niniejszego opracowania jest identyfikacja i ocena zmian w kształtowaniu się indeksów giełdowych w kontekście postępującej globalizacji rynków finansowych, a w szczególności zwrócenie uwagi na zmiany siły powiązania indeksów reprezentujących akcje spółek z różnych regionów geograficznych i krajów, a także zmiany zachodzące w zmienności tych indeksów.

Przeprowadzona analiza indeksów giełd światowych dotyczyła porównania ich kształtowania się w czasie, wyodrębnienia podokresów oraz określenia zmian w kształtowaniu się siły związków pomiędzy poszczególnymi indeksami. Pogłębionej analizy zmian zachodzących w zmienności indeksów dokonano na podstawie oszacowanych modeli GARCH. Analizą objęto łącznie 15 rynków giełdowych oraz reprezentujące je indeksy w okresie od 2 stycznia 2000 r. do 31 października 2013 r.

\section{Wstępna analiza kształtowania się indeksów giełd światowych w latach 2000-2013}

Głównym kryterium przy wyborze analizowanych rynków giełdowych, a tym samym reprezentujących je indeksów giełdowych, była wielkości kapitalizacji danej giełdy ${ }^{1}$, a także reprezentowany region geograficzny. I tak Amerykę Północną reprezentują giełdy New York Stock Exchange (indeks DJIA - Dow Jones Industrial Average), NASDAQ (indeks NASDAQ), a także Toronto Stock Exchange (indeks TSX). Następnie Europę reprezentują London Stock Exchange (indeks FTSE250 - Financial Times Stock Exchange 250), giełda paryska (indeks CAC40 - Cotation Assistée en Continu), giełda niemiecka (indeks DAX - Deutscher Aktienindex), a także giełda moskiewska (indeks RTS - Russian Trading System) i giełda warszawska (indeks WIG20 - Warszawski Indeks Giełdowy 20). W przypadku Azji wybrano z kolei giełdy w Tokio (indeks Nikkei 225 Nikkei heikin kabuka), Szanghaju (indeks Shanghai - Shanghai Stock Exchange Composite), Hongkongu (indeks Hang Seng), Bombaju (indeks SENSEX Bombay Stock Exchange Sensitive Index) oraz Australian Securities Exchange

${ }^{1}$ Uwzględniono dane dotyczące krajowej kapitalizacji giełd podane przez World Federation of Exchange, www.world-exchanges.org (data dostępu: 10.10.2013). 
(indeks All Ordinaries), a w przypadku Ameryki Łacińskiej dwie największe giełdy tego regionu: São Paulo Stock Exchange (indeks Bovespa - BOlsa de Valores dE São PAulo) oraz Mexican Stock Exchange (indeks IPC - Índice de Precios y Cotizaciones).

Dla przykładu na rys. 1 przedstawiono kształtowanie się indeksów DJIA, TSX, FTSE250, CAC40 oraz DAX w badanym okresie. Analizując kształtowanie się wszystkich indeksów, można zauważyć, że do czasu przełomu 2002/2003 indeksy w większości wykazywały trend spadkowy ze znaczną dynamiką zmian. Od 2003 r. natomiast można obserwować dość stabilną długookresową tendencję wzrostową. Trudno jednak powiedzieć, na ile utrzymywanie się tej tendencji było w danym przypadku jeszcze wynikiem uwarunkowań fundamentalnych, a na ile oznaczało już pewien poziom przewartościowania spółek.

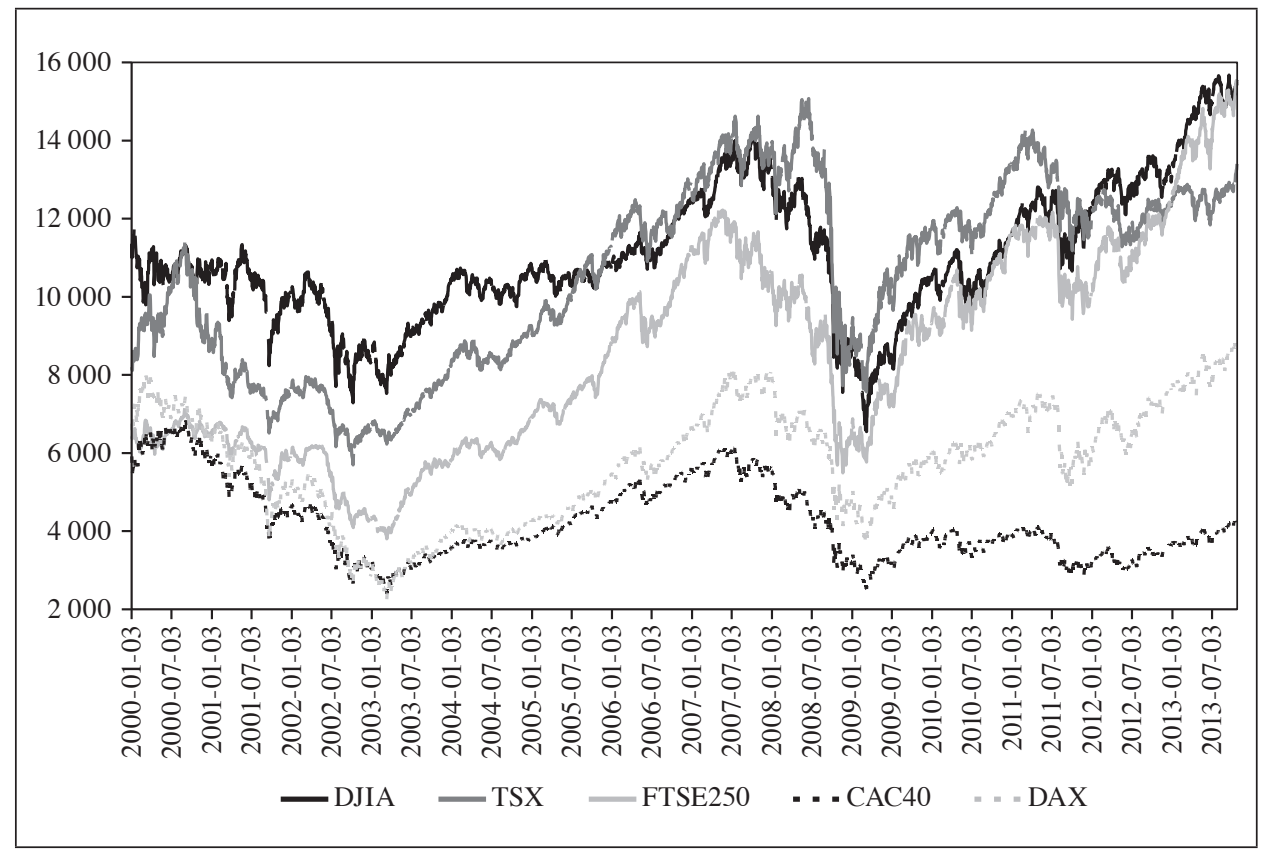

Rys. 1. Kształtowanie się indeksów w okresie 2.01.2000-31.10.20013

Źródło: opracowanie własne na podstawie danych Serwisu Informacyjnego Stooq, http://stooq.pl (data dostępu: 15.11.2013).

Większość momentów odwrócenia trendu ze wzrostowego na spadkowy przypadło na drugą połowę 2007 r. Nieco wcześniej do odwrócenia trendu doszło w przypadku indeksów dla giełdy londyńskiej i paryskiej. Natomiast indeksy RTS i Bovespa swoje maksimum osiągnęły dopiero w maju 2008 r., a TSX - w czerwcu 
2008 r. Oznacza to, że indeksy te nie zareagowały nawet na bardzo trudną sytuację w Stanach Zjednoczonych w styczniu 2008 r., kiedy nastąpiły znaczne spadki wielu indeksów giełdowych (rys. 1).

W przypadku odwrócenia trendu ze spadkowego na rosnący sytuacja była mniej zróżnicowana. Najczęściej do takiej zmiany trendu dochodziło bowiem w lutym albo marcu 2008 r., zwłaszcza 9 marca 2009 r. Nieco wcześniej doszło do odbicia indeksów RTS, Shanghai, FTSE250, a najwcześniej odbiły się ponownie indeksy Hang Seng, Bovespa i IPC. Stało się to w każdym z tych trzech przypadków 27 października 2008 r., po okresie bardzo głębokich spadków DJIA. Takie zachowanie indeksów może świadczyć o nieco lepszej kondycji tych indeksów oraz pewnej specyfice gospodarek, które reprezentują.

Pomimo zaobserwowanych znacznych różnic w sytuacji na poszczególnych rynkach należy zwrócić uwagę, że zasadniczo reakcja wszystkich analizowanych giełd na kryzys finansowy była podobna. Chociaż spadki indeksów występowały w nieco innych okresach, to ich skala mieściła się w granicach 49-80\%.

Po kryzysowych zawirowaniach dopiero w 2010 r. indeksy odzyskały względną stabilność, utrzymując w większości trend wzrostowy. Nie wszystkim jednak udało się do października 2013 r. przekroczyć szczyty z lat 2007 czy 2008. Spośród analizowanych indeksów tylko DJIA, FTSE250, DAX, SENSEX oraz IPC przekroczyły swoje najwyższe poziomy sprzed kryzysu finansowego.

Na podstawie przeprowadzonej analizy wstępnej można, jak się wydaje, wyodrębnić ogólnie 4 podstawowe okresy o zróżnicowanej charakterystyce: okres 1 od stycznia 2000 r. do grudnia 2002 r., okres 2 - od stycznia 2003 r. do połowy 2007 r., okres 3 - od lipca 2007 r. do końca 2009 r. i okres 4 - od początku 2010 r. do października $2013 \mathrm{r}$.

Kolejnym krokiem w analizie było wyliczenie dziennych stóp zwrotów (zmian) indeksów giełdowych. Na ich podstawie, przy dokładnej synchronizacji danych, obliczono średnie arytmetyczne i odchylenia standardowe dla wyodrębnionych okresów (tabela 1).

Na podstawie danych zamieszczonych w tabeli 1 można stwierdzić, że średnie stopy zwrotu indeksów w wyodrębnionych okresach kształtowały się w sposób zróżnicowany. W okresie 1 były ujemne z wyjątkiem indeksów RTS, Shanghaj i IPC, w okresie 2 wszystkie osiągnęły poziom dodatni, w kolejnym okresie zawirowań kryzysowych znowu w większości były ujemne, a w okresie 4 były w większości dodatnie. Warto zwrócić w tym kontekście uwagę na odchylenia standardowe jako miary zmienności stóp zwrotu, które w okresach 1 i 3 były, z wyjątkiem 3 przypadków, większe niż w okresach 2 i 4 . Wynika z tego, że ogólnie wraz ze spadkami indeksów wzrastała ich zmienność, co jest szczególnie widoczne w okresie 3, obejmującym kryzysowe turbulencje. Trendy wzrostowe cechowała natomiast większa stabilność, przy czym odchylenia standardowe 


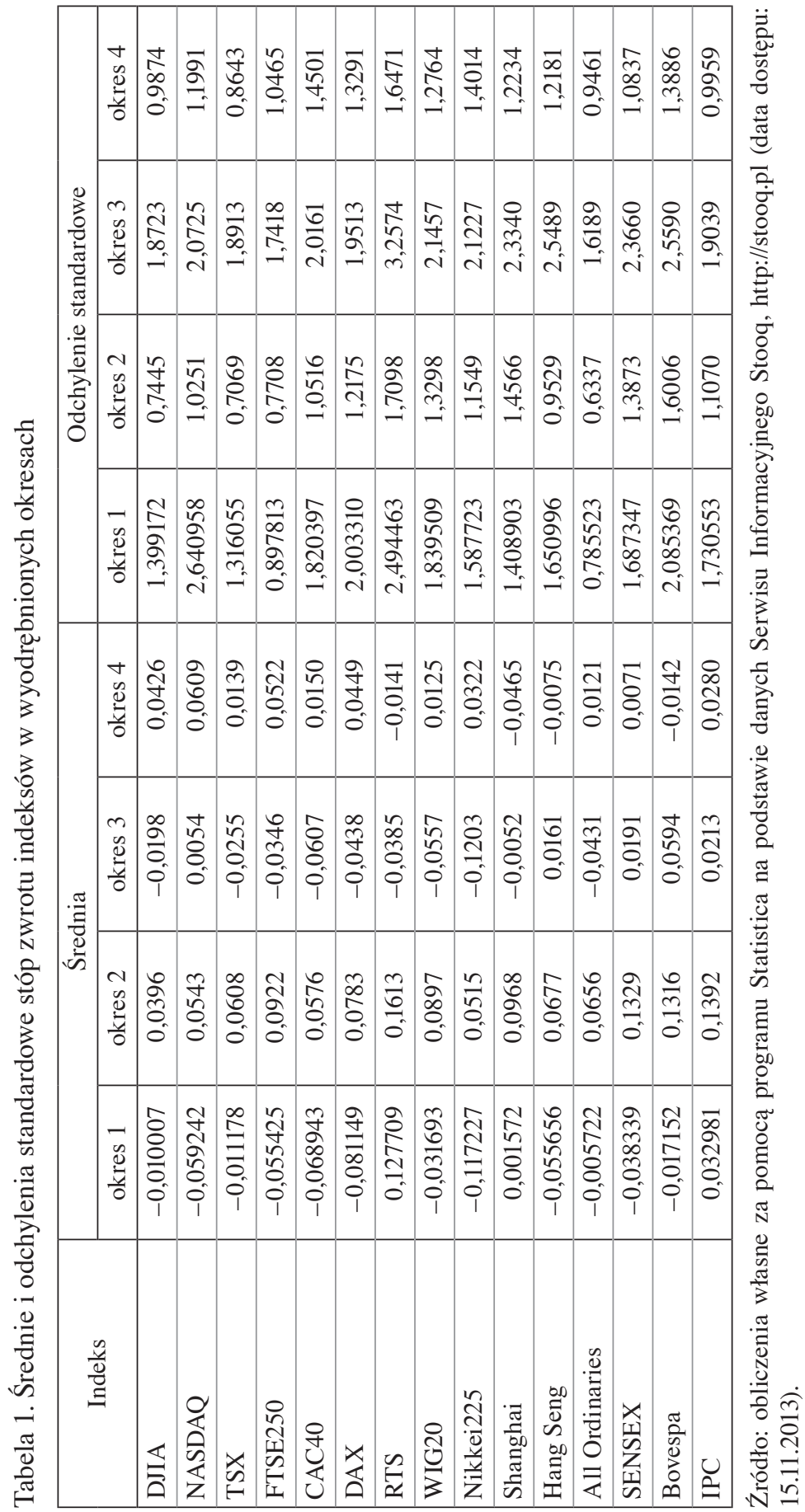


w okresie 4 ukształtowały się w większości przypadków (na największych giełdach) na nieco wyższym poziomie niż w okresie 2 . W tym ostatnim okresie, mimo utrzymywania się tendencji wzrostowych, poziom ryzyka w wielu przypadkach utrzymał się jednak na wysokim poziomie.

\section{Zmiany siły powiązań indeksów giełdowych}

Wyniki wstępnej analizy stóp zwrotu potwierdziły wybór poszczególnych okresów jako okresów o znacząco różnych charakterystykach. Wyliczone w dalszej kolejności współczynniki korelacji stóp zwrotu pozwoliły ocenić siłę związku poszczególnych indeksów w kontekście tych charakterystyk. Wyniki obliczeń dla poszczególnych okresów zawarto w tabelach 2-5. Czcionką pogrubioną zapisano współczynniki nieistotne statystycznie przy poziomie $\alpha=0,05$.

Na podstawie danych zamieszczonych w tabelach 2-5 można stwierdzić, że poziomy współczynników, z wyjątkiem nieistotnych statystycznie w okresie 1 dla indeksu Shanghaj, były dodatnie, a w poszczególnych okresach zachodziły w tym zakresie znaczące zmiany. Porównując okres 2 z okresem 1, można zauważyć, że w 77\% przypadków nastąpił wzrost współczynników korelacji, natomiast w okresie 3 (zawirowań kryzysowych) w porównaniu z okresem 2 współczynniki wzrosły w $95 \%$ przypadków. Z kolei w okresie 4 w porównaniu z okresem 3 współczynniki korelacji w 44\% zmniejszyły swój poziom.

Wskazuje to na wpływ sytuacji na giełdzie na kształtowanie się współczynników. W okresie spowodowanych kryzysem znacznych zmian poziomów indeksów i wzrostu ich zmienności współczynniki dość powszechnie i znacząco wzrosły, po czym w okresie 4 - względnej stabilizacji, duża ich część spadła. Porównując jednak okres 4 z okresem 1, można stwierdzić, z wyjątkiem 3 przypadków, znaczący wzrost współczynników. Oznacza to, że mimo okresowych wahań poziomu współczynników powodowanych sytuacją na giełdzie w zdecydowanej większości współczynniki te wzrastały w długim okresie.

Na podstawie tabeli 5 można zauważyć, że indeks największej giełdy światowej DJIA w ostatnim okresie był powiązany z 8 indeksami przy poziomie współczynników korelacji bliskich 0,7 lub powyżej tej wartości. Współczynniki dla indeksu WIG20 w 6 przypadkach osiągnęły poziom w granicach $0,5-0,7$. Analizując, który z indeksów był w ostatnim okresie powiązany w największym stopniu z pozostałymi, obliczono średnie współczynniki dla poszczególnych indeksów. Indeksem o największym stopniu powiązania okazał się FTSE250, najmniejszy stopień powiązania wykazały natomiast indeksy Shanghaj i Nikkei. Indeks Shanghaj, podobnie jak Nikkei, był przy tym najsilniej powiązany z indeksami Hang Seng i All Ordinaries. 


\begin{tabular}{|c|c|c|c|c|c|c|c|c|c|c|c|c|c|c|c|}
\hline DdI & 華 & $\sigma_{0}^{0}$ & ñ & 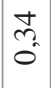 & $F_{0}$ & $\begin{array}{l}0 \\
+ \\
0 \\
0\end{array}$ & $\begin{array}{l}\hat{N} \\
0\end{array}$ & $\begin{array}{l}2 \\
1 \\
0\end{array}$ & $=$ & $\stackrel{8}{\Theta}$ & $\frac{9}{0}$ & $\frac{0}{0}$ & $\frac{m}{0}$ & $\tilde{n}$ & $\underset{-}{8}$ \\
\hline вdsәноg & $\begin{array}{l}0 \\
+ \\
0 \\
0\end{array}$ & 守 & $\stackrel{2}{I_{0}}$ & $\begin{array}{l}\tilde{2} \\
0\end{array}$ & $\vec{m}$ & $\begin{array}{l}\infty \\
2 \\
0 \\
0\end{array}$ & $\begin{array}{l}\vec{z} \\
0\end{array}$ & $\frac{a}{0}$ & $\begin{array}{l}\infty \\
0 \\
0\end{array}$ & 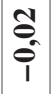 & $\begin{array}{l}8 \\
0 \\
0\end{array}$ & $\stackrel{\circ}{\circ}$ & 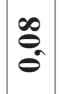 & $\stackrel{8}{-}$ & ñ \\
\hline X咟SNGS & $\stackrel{\tilde{\theta}}{\hat{\theta}}$ & $\stackrel{1}{\varrho}$ & $\stackrel{m}{0}$ & 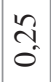 & $\frac{m}{0}$ & $\frac{\cong}{0}$ & $\begin{array}{l}\vec{n} \\
0\end{array}$ & $\frac{\infty}{0}$ & $\begin{array}{l}\vec{\jmath} \\
0\end{array}$ & $\vec{\theta}$ & 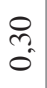 & $\begin{array}{l}\text { ¿े } \\
\text { ô }\end{array}$ & $\stackrel{8}{-}$ & $\stackrel{\infty}{\stackrel{0}{0}}$ & $\ddot{0}$ \\
\hline 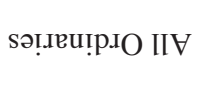 & $\hat{\theta}$ & $\stackrel{8}{\circ}$ & $\frac{1}{0}$ & 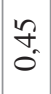 & 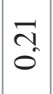 & $\frac{m}{0}$ & $\begin{array}{l}\stackrel{J}{\sim} \\
0\end{array}$ & 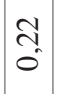 & $\begin{array}{l}g_{+} \\
0\end{array}$ & $\frac{1}{0}$ & $\tilde{n}$ & $\stackrel{8}{\circ}$ & $\begin{array}{l}0 \\
\text { N } \\
0\end{array}$ & $\stackrel{\circ}{0}$ & $\frac{0}{0}$ \\
\hline ภินәS ถินซH & $\stackrel{ \pm}{\theta}$ & $\frac{n}{0}$ & $\stackrel{\infty}{0}$ & ก & ָे & \begin{tabular}{l}
\multirow{2}{N}{} \\
0
\end{tabular} & $\begin{array}{l}n \\
\tilde{z} \\
0\end{array}$ & 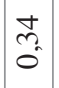 & $\begin{array}{l}n \\
n \\
0\end{array}$ & $\frac{m}{0}$ & $\underset{-}{8}$ & กี & $\begin{array}{c}0 \\
\tilde{m} \\
0\end{array}$ & ô & $\frac{9}{0}$ \\
\hline 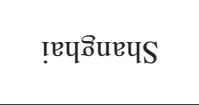 & $\begin{array}{l}\text { } \\
\hat{\theta} \\
\hat{1}\end{array}$ & ڤ̂. & है & $\hat{\theta}$ & 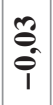 & $\begin{array}{l}\tilde{\delta} \\
\hat{\theta} \\
\hat{\theta}\end{array}$ & $\begin{array}{l} \pm \\
0 \\
\hat{\theta}\end{array}$ & $\begin{array}{l}n \\
\hat{\theta} \\
\hat{\theta}\end{array}$ & $\hat{\theta}$ & $\underset{-}{8}$ & $\stackrel{m}{0}$ & $\stackrel{1}{\circ}$ & $\vec{\theta}$ & ڤ్ & $\stackrel{8}{8}$ \\
\hline ৎZZ!əУУ!N & $\stackrel{8}{0}$ & Oे. & $\frac{n}{0}$ & ले. & $\overrightarrow{\tilde{c}}$ & $\frac{0}{0}$ & 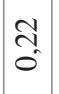 & $\begin{array}{l}\stackrel{J}{\sim} \\
0\end{array}$ & $\underset{0}{0}$ & $\hat{\theta}$ & $n^{n}$ & $\underset{\sigma}{\stackrel{g}{+}}$ & $\begin{array}{c}\vec{\pi} \\
\tilde{\sigma}\end{array}$ & 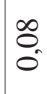 & $=$ \\
\hline OZDIM & $\frac{5}{0}$ & ก̃ & $\bar{n}$ & $\begin{array}{l}0 \\
+ \\
0 \\
0\end{array}$ & 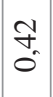 & $\begin{array}{l}\hat{n} \\
0\end{array}$ & $\begin{array}{l}\infty \\
+ \\
0\end{array}$ & $\underset{-1}{-}$ & 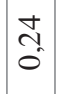 & $\begin{array}{c}n \\
\stackrel{0}{0} \\
1\end{array}$ & $\tilde{m}_{0}^{+}$ & ત̃ & $\frac{\infty}{0}$ & $\frac{9}{0}$ & ñ \\
\hline SLY & $\frac{\infty}{0}$ & ֶ̃ & స̂. & $\bar{F}_{0}$ & $\hat{n}$ & $\begin{array}{l}m \\
\tilde{o}\end{array}$ & $\underset{-1}{8}$ & $\stackrel{\infty}{+}$ & $\begin{array}{c}\tilde{N} \\
\tilde{0}\end{array}$ & 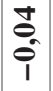 & $\stackrel{n}{n}$ & 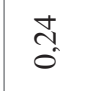 & $\begin{array}{l}\vec{n} \\
\tilde{0}\end{array}$ & $\begin{array}{l}\bar{n} \\
0\end{array}$ & సิ \\
\hline $\mathrm{X \forall C}$ & $\stackrel{2}{\circ}$ & กี & $\tilde{n}$ & $\begin{array}{c}\infty \\
n \\
n \\
0\end{array}$ & $\begin{array}{l}+ \\
\infty \\
0 \\
0\end{array}$ & $\underset{-1}{8}$ & $\begin{array}{l}\tilde{n} \\
\tilde{\sigma}\end{array}$ & $\begin{array}{l}\hat{n} \\
0\end{array}$ & $\frac{0}{0}$ & 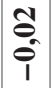 & $\begin{array}{l}\stackrel{\sim}{\sim} \\
\stackrel{0}{0}\end{array}$ & $\stackrel{m}{0}$ & $\frac{1}{0}$ & 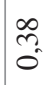 & ơ \\
\hline 0†つ৮つ & $\stackrel{n}{f_{0}}$ & సે. & o & $\begin{array}{l}\hat{\sigma} \\
0\end{array}$ & $\underset{-}{8}$ & $\begin{array}{l}+ \\
\infty \\
0\end{array}$ & $\begin{array}{l}\hat{n} \\
0\end{array}$ & $\stackrel{\substack{f \\
\hdashline}}{\circ}$ & $\begin{array}{c}\bar{n} \\
0\end{array}$ & 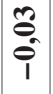 & ते & $\vec{\sim}$ & $\frac{m}{0}$ & $\overrightarrow{\tilde{\sigma}}$ & $F_{0}$ \\
\hline 0ऽZヨSLヨ & $\begin{array}{c}\stackrel{0}{0} \\
\text { ले }\end{array}$ & $\hat{ָ}$ & ñ. & $\underset{-}{\stackrel{\theta}{-}}$ & $\begin{array}{l}0 \\
0 \\
0\end{array}$ & $\begin{array}{l}\infty \\
n \\
n \\
0\end{array}$ & $\begin{array}{l}F_{0} \\
0\end{array}$ & $\begin{array}{l}0 \\
+ \\
0 \\
0\end{array}$ & ले & $\stackrel{s}{\theta}$ & กิ & $\stackrel{\text { ro }}{\circ}$ & 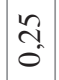 & $\stackrel{\tilde{N}}{\tilde{O}}$ & से \\
\hline XSL & $n^{n}$ & ब. & $\stackrel{8}{-}$ & $\hat{n}$ & $\begin{array}{l}0 \\
+ \\
0 \\
0\end{array}$ & $\begin{array}{l}n \\
\tilde{n} \\
0\end{array}$ & ָ̃ & $\overrightarrow{\tilde{n}}$ & $\frac{n}{0}$ & $\stackrel{8}{8}$ & $\frac{\infty}{0}$ & $\frac{n}{0}$ & $\frac{m}{0}$ & 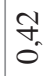 & ñ \\
\hline OVASHN & $\begin{array}{l}\hat{\sigma} \\
0\end{array}$ & $\stackrel{8}{-}$ & बे. & $\begin{array}{l}\hat{N} \\
0\end{array}$ & ले. & ก̂. & ñ & $\begin{array}{l}n \\
1 \\
0 \\
0\end{array}$ & $\stackrel{8}{0}$ & $\stackrel{0}{\hat{\theta}}$ & $\frac{n}{0}$ & $\stackrel{\circ}{\circ}$ & $\stackrel{n}{0}$ & 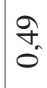 & $\overline{0}$ \\
\hline VIrd & $\underset{-}{\stackrel{8}{-}}$ & 同 & $\begin{array}{l}n \\
n \\
0\end{array}$ & $\begin{array}{c}0 \\
m \\
0 \\
0\end{array}$ & 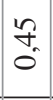 & $\begin{array}{l}2 \\
n \\
0 \\
0\end{array}$ & $\frac{\infty}{0}$ & 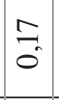 & $\begin{array}{l}0 \\
\dot{0} \\
0\end{array}$ & $\overbrace{\hat{\sigma}}$ & $\stackrel{\vec{\theta}}{\theta}$ & $\stackrel{\hat{\theta}}{\theta}$ & $\stackrel{\mathscr{\theta}}{\Theta}$ & o & 俈 \\
\hline$\frac{n}{\frac{n}{0}}$ & 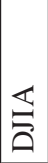 & \begin{tabular}{l}
0 \\
\multirow{2}{*}{} \\
命 \\
$z$
\end{tabular} & $\begin{array}{l}x \\
x \\
0\end{array}$ & 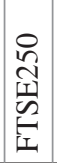 & 导 & $\begin{array}{l}x \\
\frac{a}{a}\end{array}$ & $\stackrel{\Omega}{\underline{\underline{I}}}$ & 엉 & 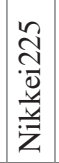 & 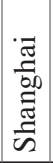 & 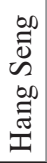 & 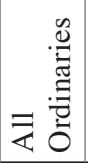 & 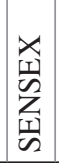 & $\begin{array}{l}\tilde{\pi} \\
\tilde{n} \\
0 \\
0 \\
0 \\
0\end{array}$ & U \\
\hline
\end{tabular}




\begin{tabular}{|c|c|c|c|c|c|c|c|c|c|c|c|c|c|c|c|c|}
\hline OdI & $\begin{array}{l}0 \\
\stackrel{2}{n} \\
0\end{array}$ & ڤn & กิ & İ & O্ & $\begin{array}{l}J_{\alpha} \\
0\end{array}$ & \begin{tabular}{l}
$\infty$ \\
\multirow{1}{0}{} \\
0
\end{tabular} & 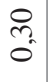 & $\overrightarrow{\tilde{o}}$ & $\begin{array}{l}0 \\
0 \\
0\end{array}$ & స్ & $\stackrel{\infty}{0}$ & $\frac{\infty}{0}$ & है. & 8 & 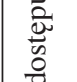 \\
\hline вdsəムоg & 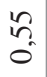 & $\stackrel{0}{n}$ & กี & के & ñ & $\hat{n}$ & $\begin{array}{l}\tilde{1} \\
\tilde{0}\end{array}$ & \begin{tabular}{l}
0 \\
\multirow{1}{0}{} \\
0
\end{tabular} & $\frac{7}{0}$ & $\overline{0}$ & กิ & $\frac{ \pm}{0}$ & $\stackrel{7}{0}$ & $\stackrel{8}{\circ}$ & ñ & 氞 \\
\hline X百SN日S & $\frac{0}{0}$ & $\stackrel{2}{0}$ & స్ & ले & $\begin{array}{l}\infty \\
\\
0\end{array}$ & ָ̃ & $\begin{array}{l}0 \\
i \\
0\end{array}$ & $\begin{array}{c}\hat{\lambda} \\
0\end{array}$ & m. & $\begin{array}{l}0 \\
\stackrel{\alpha}{0}\end{array}$ & $\stackrel{\mathscr{m}}{\sigma}$ & $\tilde{m}_{0}$ & $\underset{-}{8}$ & $\frac{7}{0}$ & $\stackrel{\infty}{0}$ & \\
\hline 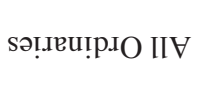 & $\stackrel{\vec{\theta}}{\theta}$ & $\stackrel{\Xi}{\theta}$ & $\frac{0}{0}$ & $\stackrel{n}{\circ}$ & 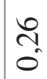 & $\begin{array}{l}\vec{N} \\
0\end{array}$ & 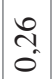 & $\begin{array}{l}\hat{n} \\
0\end{array}$ & ñ & $\begin{array}{l}1 \\
0 \\
0\end{array}$ & $\bar{n}$ & $\stackrel{8}{-}$ & $m_{0}^{m}$ & $\frac{ \pm}{0}$ & $\stackrel{\infty}{0}$ & \\
\hline 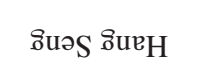 & $=$ & $\frac{n}{0}$ & $\begin{array}{l}\vec{n} \\
0\end{array}$ & $\stackrel{J}{0}_{0}^{+}$ & $\bar{\jmath}$ & \begin{tabular}{l}
$\infty$ \\
\multirow{2}{0}{} \\
0
\end{tabular} & $\begin{array}{l}\hat{n} \\
0\end{array}$ & $\hat{n}$ & ñ & $\frac{n}{0}$ & $\stackrel{8}{-}$ & $\bar{n}$ & $\stackrel{?}{\stackrel{P}{0}_{0}}$ & $\begin{array}{l}\text { त̂ } \\
0\end{array}$ & స్ & $\stackrel{8}{\infty}$ \\
\hline !̣บธินеบS & $\stackrel{\circ}{\circ}$ & $\stackrel{1}{0}$ & $\begin{array}{l}\infty \\
0 \\
0\end{array}$ & 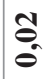 & $\stackrel{\widetilde{\sigma}}{\sigma}$ & $\stackrel{c}{\mathscr{O}}$ & $\begin{array}{l}5 \\
0 \\
0\end{array}$ & $\stackrel{\vec{\theta}}{\theta}$ & o. & $\underset{-}{8}$ & $\frac{n}{0}$ & O̊. & 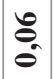 & $=$ & Oे. & \\
\hline ৎZZ!əУฯ!N & $\frac{0}{0}$ & $\frac{n}{0}$ & $\vec{\sim}$ & $\stackrel{?}{+}$ & $\overline{3}$ & $\begin{array}{l}\hat{y} \\
0\end{array}$ & $\overrightarrow{\tilde{o}}$ & 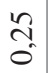 & 8 & $\hat{0}$ & in & ñ & m. & $\stackrel{1}{0}$ & ते & \\
\hline OZDIM & ָ̃ & $\overline{\tilde{o}}$ & ก̂n & 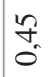 & ơ & $\begin{array}{l}\infty \\
m \\
\tilde{o}\end{array}$ & $F_{0}$ & $\underset{8}{\stackrel{8}{0}}$ & $\stackrel{2}{a}$ & $\begin{array}{l}\Delta \\
\theta \\
\theta\end{array}$ & $\hat{n}$ & $\begin{array}{l}\hat{n} \\
\text { o }\end{array}$ & $\hat{\hat{y}}$ & ㄹ. & o & \\
\hline SLY & $\frac{m}{0}$ & $\frac{m}{0}$ & స్ & $\stackrel{?}{\sigma}$ & $\vec{\sigma}$ & $\begin{array}{l}0 \\
\text { N } \\
0\end{array}$ & $\underset{-}{8}$ & $\vec{\sigma}$ & $\overrightarrow{\tilde{o}}$ & $\begin{array}{l}\hat{0} \\
0\end{array}$ & స̃ & $\begin{array}{l}\stackrel{1}{1} \\
\text { o }\end{array}$ & \begin{tabular}{l}
0 \\
\multirow{1}{1}{} \\
0
\end{tabular} & Ñ & $\begin{array}{l}\infty \\
\\
0\end{array}$ & \\
\hline $\mathrm{X \forall C}$ & $\tilde{n}$ & n & ơ & శె. & $\begin{array}{l}\infty \\
\infty \\
0\end{array}$ & 8 & $\begin{array}{l}0 \\
i \\
0\end{array}$ & $\begin{array}{l}\infty \\
m \\
0\end{array}$ & $\hat{N}_{0}$ & $\stackrel{\tilde{O}}{\sigma}$ & 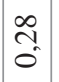 & $\overrightarrow{\widetilde{N}}$ & ஸి & ñ & $\overbrace{0}^{+}$ & \\
\hline 0†วサつ & ?̊n. & 于े & $\vec{\sigma}_{0}$ & î. & $\stackrel{8}{\circ}$ & $\begin{array}{l}\infty \\
\infty \\
0 \\
0\end{array}$ & $\bar{m}$ & 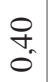 & $\vec{m}$ & $\stackrel{\tilde{\sigma}}{\sigma}$ & $\overrightarrow{\tilde{m}_{2}}$ & 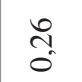 & \begin{tabular}{l}
$\infty$ \\
\multirow{1}{1}{} \\
0
\end{tabular} & $\begin{array}{l}n \\
n \\
0\end{array}$ & J্ & \\
\hline 0SZヨSLH & m. & $\tilde{m}_{0}$ & $\begin{array}{l}\infty \\
m \\
0\end{array}$ & $\stackrel{8}{-}$ & ô. & $\begin{array}{l}\tilde{\sigma} \\
0\end{array}$ & $\stackrel{\mathscr{P}}{\circ}$ & $\stackrel{n}{\stackrel{n}{0}}$ & $\stackrel{\mathscr{\vartheta}}{\leftrightarrow}$ & $\stackrel{\tilde{\sigma}}{\sigma}$ & $\underset{0}{+}$ & $\stackrel{n}{\circ}$ & ले & 志 & $\stackrel{\text { I }}{0}$ & \\
\hline XSL & 敬 & 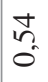 & 8 & $\begin{array}{l}\infty \\
0 \\
0 \\
0\end{array}$ & F & $\begin{array}{l}0 \\
\stackrel{+}{+} \\
0\end{array}$ & î & 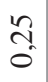 & $\overrightarrow{\widetilde{d}}$ & $\begin{array}{l}\infty \\
0 \\
0 \\
0\end{array}$ & $\vec{\sim}$ & $\stackrel{0}{0}$ & $\overrightarrow{\widetilde{N}}$ & กี & กิ & \\
\hline OVASVN & $\begin{array}{l}\mathscr{1} \\
\infty \\
0 \\
0\end{array}$ & $\stackrel{8}{8}$ & 俈 & m. & テे & $\begin{array}{l}n \\
n \\
0\end{array}$ & $\frac{m}{0}$ & $\overrightarrow{\tilde{N}}$ & $\frac{n}{0}$ & $\stackrel{1}{0}$ & $\frac{n}{0}$ & $\stackrel{\vec{\theta}}{\theta}$ & $\stackrel{\sim}{\Im}$ & ஜn & ڤn & \\
\hline VIfC & $\stackrel{8}{\circ}$ & $\begin{array}{l}n \\
\infty \\
0\end{array}$ & 年 & ?. & ס̊ & $\begin{array}{l}n \\
0 \\
0\end{array}$ & $\frac{m}{0}$ & 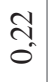 & $\frac{0}{0}$ & $\begin{array}{l}0 \\
\stackrel{0}{0} \\
\theta\end{array}$ & $=$ & $\stackrel{\vec{\theta}}{\theta}$ & $\stackrel{0}{\circ}$ & n & $\begin{array}{l}\circ \\
n \\
0\end{array}$ & \\
\hline$\frac{n}{\frac{n}{0}}$ & 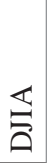 & 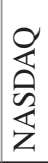 & $\begin{array}{l}x \\
\qquad \\
\omega\end{array}$ & 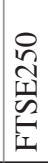 & 导 & $\underset{x}{x}$ & $\stackrel{\mathscr{n}}{\underline{\omega}}$ & 灾 & 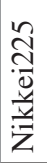 & 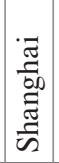 & $\begin{array}{l}00 \\
\tilde{D} \\
\tilde{N} \\
00 \\
\tilde{\Xi} \\
\tilde{I}\end{array}$ & 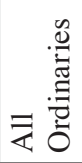 & 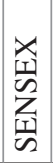 & $\begin{array}{l}\tilde{0} \\
0 \\
0 \\
0 \\
0 \\
0\end{array}$ & U & ले \\
\hline
\end{tabular}




\begin{tabular}{|c|c|c|c|c|c|c|c|c|c|c|c|c|c|c|c|}
\hline DdI & $\frac{2}{0}$ & $\begin{array}{l}0 \\
\infty \\
0 \\
0\end{array}$ & $\begin{array}{l}\tilde{U} \\
\dot{0} \\
0\end{array}$ & 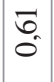 & $\begin{array}{l}\tilde{0} \\
0 \\
0\end{array}$ & $\begin{array}{l}\hat{\sigma} \\
0\end{array}$ & $\begin{array}{l}0 \\
+ \\
0 \\
0\end{array}$ & $\begin{array}{c}0 \\
\tilde{n} \\
0\end{array}$ & 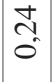 & $\stackrel{\simeq}{0}$ & ले. & $\overrightarrow{\tilde{~}}$ & $\tilde{n}$ & $\begin{array}{l}0 \\
\infty \\
\infty \\
0\end{array}$ & $\stackrel{8}{-}$ \\
\hline вdsәноg & $\frac{\hat{\sigma}}{0}$ & $\frac{\infty}{\infty}$ & $\stackrel{2}{0}$ & $\begin{array}{l}n \\
0 \\
0\end{array}$ & $\begin{array}{l}\tilde{0} \\
0 \\
0\end{array}$ & $\begin{array}{l}t \\
0 \\
0\end{array}$ & $\stackrel{\infty}{+}$ & $\begin{array}{c}0 \\
n \\
0\end{array}$ & 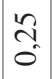 & $\frac{9}{0}$ & $\underset{f}{\stackrel{Y}{0}}$ & $\begin{array}{l}\text { กิ } \\
\text { லิ }\end{array}$ & $\hat{n}$ & $\underset{-}{8}$ & $\begin{array}{l}\infty \\
\infty \\
0 \\
0\end{array}$ \\
\hline X百SNヨS & से. & $\begin{array}{c}0 \\
\tilde{n} \\
0\end{array}$ & $\overrightarrow{\tilde{n}}$ & 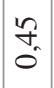 & $\stackrel{\mathscr{F}}{\tilde{\sigma}}$ & $\begin{array}{l}f_{0} \\
0\end{array}$ & 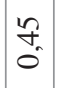 & $\stackrel{\infty}{\infty}_{0}^{+}$ & $\stackrel{\leftrightarrow}{\leftrightarrow}$ & $\begin{array}{l}n \\
\tilde{0}\end{array}$ & $\begin{array}{l}\sigma_{0} \\
0\end{array}$ & $\stackrel{n}{\stackrel{n}{o}}$ & $\stackrel{8}{-}$ & $\hat{n}$ & ñ \\
\hline sә!ıвu!pıO IIV & $=$ & $\stackrel{\hat{\theta}}{\hat{\theta}}$ & 오 & $\begin{array}{c}\infty \\
\cdots \\
0 \\
?\end{array}$ & $\begin{array}{l}0 \\
2 \\
0 \\
0\end{array}$ & $\begin{array}{l}\tilde{2} \\
\tilde{0}\end{array}$ & $\begin{array}{c}0 \\
\tilde{n} \\
0\end{array}$ & $\begin{array}{c}m \\
\tilde{o} \\
0\end{array}$ & $\frac{n}{0}$ & $\begin{array}{l}0 \\
\text { n. } \\
0\end{array}$ & $\hat{\sigma}_{0}$ & 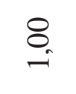 & $\stackrel{n}{\circ}$ & ત̃ & స̃ \\
\hline ภิuəs ภิurH & \begin{tabular}{l}
$\infty$ \\
\multirow{1}{0}{} \\
0
\end{tabular} & \begin{tabular}{l}
$n$ \\
\multirow{2}{n}{} \\
0
\end{tabular} & $\begin{array}{l}\tilde{n} \\
\tilde{z} \\
\tilde{\sigma}\end{array}$ & $\underset{0}{\underbrace{}_{0}}$ & $\begin{array}{c}2 \\
\text { ले } \\
0\end{array}$ & $\begin{array}{l}0 \\
+ \\
0\end{array}$ & $\begin{array}{c} \pm \\
n \\
0 \\
0\end{array}$ & $F_{\dot{\sigma}}$ & $\vec{\sigma}$ & $\bar{n}$ & $\underset{-}{8}$ & $\hat{\sigma}_{0}$ & $\begin{array}{l}\dot{J} \\
0\end{array}$ & $\stackrel{\Im}{\stackrel{f}{0}}$ & ले \\
\hline เ̣ణบชินеपS & $\stackrel{\overbrace{}}{\theta}$ & $\stackrel{\widetilde{\sigma}}{\theta}$ & $=$ & $\frac{ \pm}{0}$ & $\begin{array}{l}0 \\
0 \\
0\end{array}$ & $\begin{array}{l}0 \\
0 \\
0\end{array}$ & $\begin{array}{l}\vec{\lambda} \\
0\end{array}$ & $\frac{n}{0}$ & $\stackrel{n}{\approx}$ & $\underset{8}{8}$ & $\vec{n}$ & 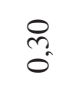 & $\stackrel{m}{m}$ & $\frac{2}{0}$ & $\stackrel{ }{\circ}$ \\
\hline ৎZZ!əУҮ!N & $\exists$ & $\stackrel{\infty}{\stackrel{0}{\theta}}$ & $\begin{array}{l}\hat{n} \\
\tilde{0}\end{array}$ & ơ & $\begin{array}{l}\hat{n} \\
0\end{array}$ & $\begin{array}{l}\dot{J} \\
\tilde{O} \\
0\end{array}$ & $\underset{\dot{f}}{\stackrel{q}{o}}$ & $\begin{array}{c}1 \\
\tilde{2} \\
0\end{array}$ & $\underset{-}{8}$ & $\begin{array}{l}n \\
\tilde{o} \\
0\end{array}$ & $\vec{\sigma}$ & $\frac{n}{0}$ & $\stackrel{\mathscr{\vartheta}}{\circ}$ & $\begin{array}{l}n \\
\mathfrak{n} \\
0\end{array}$ & 竝 \\
\hline OZDIM & ले. & $\hat{n}$ & ơ & 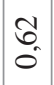 & $\begin{array}{l}\tilde{\sigma} \\
0 \\
0\end{array}$ & $\begin{array}{l}\bar{\sigma} \\
0\end{array}$ & $\begin{array}{l}\tilde{\sigma} \\
0 \\
0\end{array}$ & $\underset{\Omega}{\mathscr{O}}$ & त̂ & $\frac{n}{0}$ & $\vec{F}_{0}$ & $\stackrel{m}{2}$ & $\stackrel{\infty}{\stackrel{\infty}{+}}$ & $\begin{array}{l}n \\
0 \\
0\end{array}$ & ก̊ \\
\hline SLY & 尺े. & $\begin{array}{l}\infty \\
1 \\
0 \\
0\end{array}$ & $\stackrel{\mathscr{P}}{\stackrel{\sigma}{0}}$ & $\begin{array}{l}\tilde{\sigma} \\
0 \\
0\end{array}$ & $\begin{array}{c}\infty \\
n \\
0 \\
0\end{array}$ & $\begin{array}{l}n \\
0 \\
0\end{array}$ & $\underset{-}{\stackrel{g}{-}}$ & $\begin{array}{l}\tilde{\sigma} \\
0 \\
0\end{array}$ & 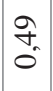 & $\vec{n}$ & 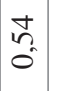 & $\begin{array}{l}n \\
0 \\
0\end{array}$ & $\stackrel{r}{\stackrel{f}{0}}$ & $\stackrel{\infty}{+\infty}$ & o \\
\hline $\mathrm{X} \forall \mathrm{C}$ & ర్ర్ & $\begin{array}{l}\tilde{n} \\
0 \\
0\end{array}$ & $\begin{array}{l}n \\
n \\
0\end{array}$ & $\frac{2}{0}$ & $\tilde{\sigma}$ & 8 & $\begin{array}{l}n \\
n \\
0\end{array}$ & 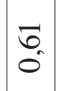 & 它. & $\frac{0}{0}$ & 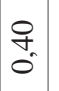 & तै & $\stackrel{J}{0}_{0}$ & $\begin{array}{l}\text { ț } \\
\text { Oे }\end{array}$ & రీ \\
\hline 0†つサว & ڤn & 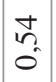 & $\begin{array}{c}n \\
\tilde{0} \\
0\end{array}$ & 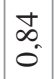 & $\underset{-}{8}$ & $\begin{array}{l}\sigma \\
\sigma \\
\sigma\end{array}$ & $\begin{array}{c}\infty \\
n \\
n \\
0\end{array}$ & $\begin{array}{l}\tilde{\sigma} \\
0 \\
0\end{array}$ & $\hat{n}$ & $\stackrel{0}{0}$ & ले & $\begin{array}{l}0 \\
\text { ?. } \\
0\end{array}$ & $\stackrel{\mathscr{P}}{\circ}$ & $\begin{array}{l}\text { to } \\
\text { Oे }\end{array}$ & $\begin{array}{l}\text { t. } \\
0\end{array}$ \\
\hline 0ऽZヨSLH & 字 & $\hat{\sigma}_{0}$ & $\vec{n}$ & $\underset{-}{8}$ & $\begin{array}{l}\overrightarrow{1} \\
\infty \\
0\end{array}$ & $\frac{2}{0}$ & $\begin{array}{l}\tilde{\sigma} \\
0 \\
0\end{array}$ & $\begin{array}{l}\tilde{\sigma} \\
0 \\
0\end{array}$ & O⿱ & $\stackrel{ \pm}{0}$ & $\stackrel{J}{0}_{0}$ & 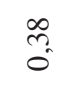 & 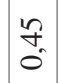 & ñ & $\overrightarrow{0}$ \\
\hline XSL & $\underset{0}{0}$ & $\begin{array}{l}\tilde{\sigma} \\
0 \\
0\end{array}$ & $\underset{-}{8}$ & $\vec{n}$ & กิ & $\begin{array}{l}\stackrel{n}{n} \\
0\end{array}$ & $\underset{\tilde{F}}{\tilde{\sigma}}$ & $\begin{array}{l}0 \\
+ \\
0 \\
0\end{array}$ & $\begin{array}{l}\hat{y} \\
0\end{array}$ & $=$ & $\stackrel{n}{\tilde{n}}$ & $\begin{array}{c}\text { तิ } \\
\text { o }\end{array}$ & $\overrightarrow{\tilde{o}}$ & $\stackrel{R}{0}$ & $\begin{array}{l}\text { t } \\
0\end{array}$ \\
\hline 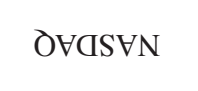 & $\tilde{\sigma}$ & $\underset{-1}{8}$ & $\begin{array}{l}\tilde{b} \\
0 \\
0\end{array}$ & $\tilde{f}_{0}^{+}$ & $\begin{array}{l}\dot{n} \\
\tilde{o}\end{array}$ & $\begin{array}{l}2 \\
\tilde{n} \\
0\end{array}$ & $\begin{array}{l}\infty \\
\\
0\end{array}$ & $\begin{array}{c}n \\
\tilde{n} \\
0\end{array}$ & 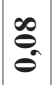 & $\begin{array}{l}\tilde{\sigma} \\
\hat{\sigma}\end{array}$ & $\stackrel{n}{n}$ & $\stackrel{5}{\Theta}$ & $\begin{array}{c}0 \\
\text { m. } \\
0\end{array}$ & $\frac{\infty}{\sigma}$ & 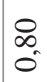 \\
\hline VIrd & $\stackrel{8}{\circ}$ & $\begin{array}{l}n \\
\sigma \\
0\end{array}$ & $\begin{array}{l}0 \\
0 \\
0\end{array}$ & $\begin{array}{c}\tilde{f}_{0} \\
\tilde{0}\end{array}$ & $\begin{array}{l}n \\
n \\
n \\
0\end{array}$ & $\begin{array}{l}\tilde{\sigma} \\
0 \\
0\end{array}$ & $\begin{array}{c}0 \\
m \\
\text { m. } \\
0\end{array}$ & $\begin{array}{c}\hat{m} \\
\hat{0}\end{array}$ & $\exists$ & $\stackrel{\theta}{\Theta}$ & 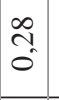 & $\exists$ & $\vec{m}_{0}^{+}$ & $\stackrel{\hat{n}}{0}$ & $\stackrel{2}{0}$ \\
\hline$\frac{\frac{n}{0}}{\Xi}$ & $\underset{\overparen{D}}{\leftrightarrows}$ & 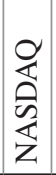 & $\begin{array}{l}x \\
\qquad \\
\Leftrightarrow\end{array}$ & 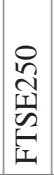 & 导 & $\begin{array}{l}x \\
\stackrel{x}{a} \\
\end{array}$ & $\stackrel{\mathscr{E}}{\mathscr{\mathscr { U }}}$ & $\begin{array}{l}\text { ป̂. } \\
\text { క } \\
3\end{array}$ & 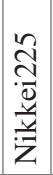 & 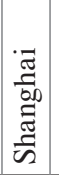 & $\begin{array}{l}00 \\
\tilde{D} \\
\tilde{D} \\
00 \\
\tilde{E} \\
\tilde{\Xi} \\
\end{array}$ & 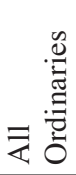 & 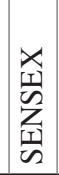 & $\begin{array}{l}\tilde{a} \\
\tilde{0} \\
0 \\
0 \\
0 \\
0\end{array}$ & U \\
\hline
\end{tabular}




\begin{tabular}{|c|c|c|c|c|c|c|c|c|c|c|c|c|c|c|c|c|}
\hline OdI & $\overrightarrow{0}$ & बे. & 芯 & $\tilde{n}$ & ñ & $\begin{array}{l}n \\
n \\
0\end{array}$ & $\tilde{n}$ & ơ & $\frac{n}{0}$ & $\frac{0}{0}$ & $\begin{array}{l}0 \\
i \\
0 \\
0\end{array}$ & $\stackrel{\overbrace{}}{0}$ & $\begin{array}{l}\tilde{m} \\
\tilde{0}\end{array}$ & ชె. & $\stackrel{8}{-}$ & 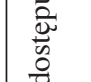 \\
\hline edsəıоg & \begin{tabular}{l}
$\infty$ \\
\multirow{0}{0}{} \\
0
\end{tabular} & $\begin{array}{l}\infty \\
0 \\
0\end{array}$ & $\begin{array}{l}0 \\
0 \\
0\end{array}$ & $\begin{array}{l}n \\
\tilde{n} \\
0\end{array}$ & ñ & 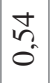 & $\begin{array}{l}\vec{\sigma} \\
\ddot{0}\end{array}$ & $\stackrel{r}{\stackrel{r}{o}}$ & $\begin{array}{l}8 \\
0 \\
0\end{array}$ & గి & $\begin{array}{l}0 \\
\text { m. } \\
0\end{array}$ & 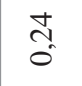 & $\begin{array}{l}\tilde{2} \\
\tilde{0}\end{array}$ & $\stackrel{8}{\circ}$ & రై & ह \\
\hline X百SN日S & $\begin{array}{l}\infty \\
\stackrel{1}{0} \\
0\end{array}$ & \begin{tabular}{c}
$\infty$ \\
\multirow{1}{0}{} \\
0
\end{tabular} & $\hat{m}$ & $\mid \begin{array}{l}\infty \\
+ \\
0\end{array}$ & $\underset{\mathscr{\vartheta}}{\stackrel{\vartheta}{\sigma}}$ & 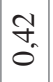 & $\overbrace{0}^{+}$ & $\stackrel{\mathscr{P}}{\stackrel{\circ}{\circ}}$ & $\begin{array}{l}0 \\
\text { n. } \\
0\end{array}$ & ָ̊ & 苴 & $\begin{array}{c}\infty \\
\text { m. } \\
0\end{array}$ & $\underset{-}{8}$ & 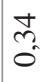 & से. & $\frac{8}{2}$ \\
\hline sə!.ıu!̣p.IO IIV & 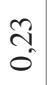 & ํ. & $\overrightarrow{m_{0}}$ & $\begin{array}{l}\infty \\
+ \\
0\end{array}$ & $\begin{array}{l}\hat{n} \\
0\end{array}$ & $\begin{array}{l}0 \\
\text { na } \\
0\end{array}$ & $\begin{array}{l}\infty \\
m_{0} \\
0\end{array}$ & $\overrightarrow{\tilde{o}}$ & స్ర & 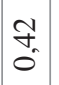 & $\stackrel{R}{0}$ & $\stackrel{8}{\circ}$ & $\begin{array}{l}\infty \\
m \\
0\end{array}$ & 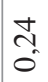 & $\begin{array}{l}\hat{2} \\
0 \\
0\end{array}$ & \\
\hline ภ̊uəs ภิurH & $\frac{\infty}{0}$ & 尺ి & సे & 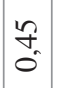 & $\hat{n}$ & $\hat{n}$ & $\underset{\dot{\theta}}{\dot{I}_{0}}$ & 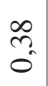 & $\begin{array}{l}0 \\
n \\
0\end{array}$ & $\begin{array}{l}n \\
0 \\
0\end{array}$ & $\underset{-}{8}$ & $\frac{?}{0}$ & $\tilde{n}_{0}^{+}$ & 尺) & 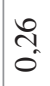 & $\begin{array}{l}8 \\
\stackrel{8}{\mathscr{d}}\end{array}$ \\
\hline !̣บภินеบS & $\stackrel{\sim}{\stackrel{0}{0}}$ & $\frac{n}{0}$ & ป̃ & $\begin{array}{l}\tilde{\lambda} \\
0\end{array}$ & $\overrightarrow{\tilde{N}}$ & $\begin{array}{l}\text { 尺̂. } \\
\text { o }\end{array}$ & $\hat{\tilde{o}}$ & $\begin{array}{c}\text { તิ } \\
\text { ô }\end{array}$ & $\begin{array}{l}\dot{z} \\
\tilde{z} \\
0\end{array}$ & $\underset{8}{8}$ & $\begin{array}{l}n \\
\tilde{n} \\
\alpha\end{array}$ & ণ্ণ & \begin{tabular}{c}
0 \\
\multirow{1}{1}{} \\
0
\end{tabular} & సે & $\frac{9}{0}$ & \\
\hline ৎZZ!əУฯ!N & $\stackrel{ \pm}{ \pm}$ & $\frac{0}{0}$ & $\stackrel{\infty}{0}$ & $\begin{array}{l}n \\
n \\
0\end{array}$ & $\begin{array}{l}n \\
1 \\
0\end{array}$ & $\begin{array}{l}\stackrel{0}{1} \\
\text { in } \\
0\end{array}$ & $\hat{\sim}_{0}$ & $\overrightarrow{\tilde{N}}$ & 8 & $\begin{array}{l}+ \\
\text { m. }\end{array}$ & $\begin{array}{l}n \\
n \\
0\end{array}$ & $\begin{array}{l}\text { Tु } \\
\text { Oे }\end{array}$ & $\begin{array}{l}0 \\
\text { m. } \\
0\end{array}$ & o. & $\frac{n}{0}$ &. \\
\hline 0ZDIM & ก̃ & م & $\begin{array}{l}F_{0} \\
\tilde{O}^{\prime}\end{array}$ & $\left|\begin{array}{l}0 \\
0 \\
0\end{array}\right|$ & $\mid \begin{array}{l}\infty \\
0 \\
0 \\
0\end{array}$ & $\begin{array}{l}\hat{b} \\
0 \\
0\end{array}$ & $\begin{array}{l}\widehat{6} \\
0\end{array}$ & $\stackrel{8}{8}$ & $\vec{n}$ & ָ̊. & $\begin{array}{l}\infty \\
\cdots \\
0 \\
0\end{array}$ & $\begin{array}{l}\bar{m} \\
\hat{0}\end{array}$ & $\stackrel{\mathscr{P}}{\mathscr{\sigma}}$ & 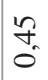 & ơ & \\
\hline SLY & $\begin{array}{l}\text { gे } \\
\text { O }\end{array}$ & ஜ: & $\begin{array}{l}\text { J } \\
0 \\
0\end{array}$ & $\frac{m}{0}$ & $\vec{\sigma}$ & $\vec{\sigma}$ & $\underset{-}{8}$ & $\underset{6}{6}$ & $\begin{array}{l}\hat{N} \\
0\end{array}$ & $\hat{ָ}$ & $\underset{8}{+}$ & $\begin{array}{c}\infty \\
\stackrel{n}{0} \\
\sigma_{0}\end{array}$ & $\overbrace{0}^{+}$ & ర్. & ñ & \\
\hline $\mathrm{X} \forall \mathrm{C}$ & 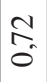 & $\begin{array}{l}\hat{\sigma} \\
0\end{array}$ & $\begin{array}{l}3 \\
6 \\
0\end{array}$ & $\begin{array}{l}\hat{\infty} \\
0\end{array}$ & $\hat{\sigma}$ & $\underset{-}{8}$ & $\vec{\sigma}$ & $\begin{array}{l}\hat{b} \\
0\end{array}$ & $\begin{array}{l}\stackrel{2}{1} \\
0\end{array}$ & 尺ి & $\hat{n}$ & $\begin{array}{l}0 \\
\text { m. } \\
0\end{array}$ & 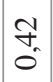 & 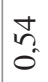 & n & \\
\hline 0†วНว & $\vec{\sigma}$ & $\begin{array}{l}\infty \\
0 \\
0\end{array}$ & $\begin{array}{l}3 \\
0 \\
0\end{array}$ & $\begin{array}{c}+ \\
\infty \\
0\end{array}$ & $\underset{0}{8}$ & $\hat{\sigma}$ & $\vec{\sigma}$ & $\begin{array}{l}\infty \\
0 \\
0 \\
0\end{array}$ & $\begin{array}{l}2 \\
\tilde{0} \\
0\end{array}$ & $\vec{N}$ & $\hat{n}$ & $\hat{n}$ & $\stackrel{\mathscr{F}}{\mathscr{\sigma}}$ & $\begin{array}{l}n \\
n \\
0\end{array}$ & $\begin{array}{l}n \\
n \\
0\end{array}$ & \\
\hline 0SZGSLH & $\begin{array}{l}0 \\
0 \\
0\end{array}$ & $\begin{array}{l}\text { to } \\
0\end{array}$ & $\begin{array}{l}\widetilde{0} \\
0 \\
0\end{array}$ & $\stackrel{8}{-}$ & $\begin{array}{l}\overrightarrow{1} \\
\infty \\
0\end{array}$ & $\begin{array}{l}\mathscr{2} \\
\infty \\
0\end{array}$ & $\frac{m}{\sigma}$ & $\begin{array}{l}0 \\
0 \\
0\end{array}$ & $\begin{array}{l}n \\
\tilde{0}\end{array}$ & $\begin{array}{l}\hat{y} \\
\hat{0}\end{array}$ & $\stackrel{n}{+}$ & $\stackrel{\infty}{\stackrel{\infty}{0}}$ & 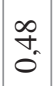 & $\tilde{n}$ & $\tilde{n}$ & \\
\hline XSL & $\frac{n}{0}$ & $\frac{0}{0}$ & $\underset{-}{8}$ & $\begin{array}{l}\tilde{\sigma} \\
0 \\
0\end{array}$ & గి. & $\begin{array}{l}3 \\
0 \\
0\end{array}$ & $\begin{array}{l}\overrightarrow{0} \\
\ddot{0}\end{array}$ & $\stackrel{f}{f}$ & $\stackrel{\infty}{0}$ & $\begin{array}{l}\tilde{N} \\
0\end{array}$ & ì & $\overrightarrow{3}$ & $\tilde{m}_{0}$ & $\begin{array}{l}0 \\
0 \\
0\end{array}$ & 吉 & \\
\hline OVGS & ふ઼ & $\stackrel{8}{8}$ & $\frac{0}{2}$ & $\begin{array}{l}\overrightarrow{0} \\
0\end{array}$ & $\begin{array}{l}\infty \\
0 \\
0 \\
0\end{array}$ & O్రి & $\begin{array}{l}0 \\
0 \\
0\end{array}$ & ? & $\frac{0}{0}$ & $\frac{n}{0}$ & $\begin{array}{l}\stackrel{1}{1} \\
\text { o. }\end{array}$ & $\begin{array}{c}\text { İ } \\
0\end{array}$ & \begin{tabular}{l}
$\infty$ \\
\multirow{1}{0}{} \\
0
\end{tabular} & $\begin{array}{l}\infty \\
0 \\
0\end{array}$ & i. & \\
\hline VIrd & $\stackrel{8}{\circ}$ & ふু & $\frac{n}{0}$ & $\begin{array}{l}0 \\
0 \\
0\end{array}$ & $\vec{\sigma}$ & $\stackrel{N}{\stackrel{N}{0}}$ & $\begin{array}{l}\hat{b} \\
0\end{array}$ & ñ & $\frac{ \pm}{0}$ & $\stackrel{2}{0}$ & $\frac{\infty}{0}$ & $\stackrel{\tilde{z}}{\tilde{0}}$ & \begin{tabular}{l}
$\infty$ \\
\multirow{2}{1}{} \\
0
\end{tabular} & $\begin{array}{l}\infty \\
0 \\
0\end{array}$ & $\overline{0}$ & \\
\hline $\begin{array}{l}\frac{\tilde{u}}{\tilde{\theta}} \\
\Xi\end{array}$ & $\underset{\overparen{D}}{\leftrightarrows}$ & \begin{tabular}{l}
0 \\
\multirow{2}{1}{} \\
会 \\
z
\end{tabular} & $\begin{array}{l}x \\
x \\
\omega \\
H\end{array}$ & 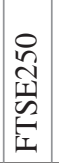 & 导 & $\begin{array}{l}x \\
\frac{a}{a}\end{array}$ & $\stackrel{\mathscr{E}}{\widetilde{\alpha}}$ & $\begin{array}{l}\text { N్ } \\
\stackrel{3}{3}\end{array}$ & 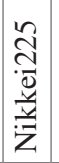 & 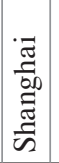 & $\begin{array}{l}000 \\
\tilde{D} \\
\tilde{N} \\
000 \\
\tilde{\Xi} \\
\tilde{I}\end{array}$ & 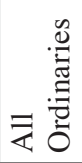 & 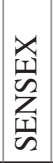 & $\begin{array}{l}\tilde{2} \\
0 \\
0 \\
0 \\
0 \\
0\end{array}$ & U & ले \\
\hline
\end{tabular}


Ogólnie indeksy giełd azjatyckich były w mniejszym stopniu powiązane z pozostałymi, ale też względem siebie. $W$ ich przypadku jednak także można obserwować wzrost współczynników w długim okresie.

Podsumowując, należy zwrócić uwagę, że uzyskane wyniki mogą być obarczone błędem wynikającym z wybranych okresów porównań. Ostatni okres może się okazać zbyt krótki, aby wyciągać daleko idące wnioski. Być może wraz z dalszą stabilizacją sytuacji na giełdach współczynniki korelacji będą się obniżać. Jak zaznaczono wcześniej, poziom zmienności może odgrywać znaczącą rolę w kształtowaniu się współczynników korelacji.

\section{Identyfikacja i ocena zmian poziomów zmienności wybranych indeksów giełdowych}

W tej części przedmiotem pogłębionej analizy była zmienność indeksów giełdowych. W analizie tej zastosowano modele zmienności GARCH, a dokładniej w celu przeprowadzenia porównań zmienności wybrano jedną postać modelu AR(1)-GARCH(1,1) z rozkładem błędu $t$-Studenta, którą zastosowano w odniesieniu do wszystkich indeksów.

Ogólną reprezentację liniowych modeli gaussowskich stosowanych do analizy szeregów czasowych stanowi model $\operatorname{ARMA}(p, q)$ (autoregressive moving average) o postaci:

$$
r_{t}=a_{0}+\sum_{j=1}^{p} a_{j} r_{t-j}+\varepsilon_{t}-\sum_{j=1}^{q} b_{j} \varepsilon_{t-j},
$$

gdzie: $r_{t}$ oznacza logarytmiczną stopę zwrotu, $a_{0}, a_{j} \mathrm{i} b_{j}$ - parametry modelu, a $\varepsilon_{t}$ to niezależne i o tym samym rozkładzie zmienne losowe ze średnią zero i skończoną wariancją. Model $\operatorname{ARMA}(p, 0)$ jest modelem autoregresyjnym rzędu $p$, oznaczanym przez $\operatorname{AR}(p)$.

Podstawowym ustaleniem dla modelowania zmian w wariancji było określenie stopy zwrotu $r_{t}$ jako sumy o postaci (zob. [Doman i Doman 2009, s. 76-79]):

$$
r_{t}=\mu_{t}+\varepsilon_{t},
$$

gdzie $\mu_{t}$ oznacza średnią warunkową, opisywaną zazwyczaj za pomocą modelu $\operatorname{ARMA}(p, q)$, a $\varepsilon_{t}-$ innowację w średniej, określaną jako ciąg niezależnych i o tym samym rozkładzie (iid, ang. independent and identically distributed) zmiennych losowych $z_{t}$ ze średnią zero i wariancją jeden, pomnożonych przez odchylenie standardowe $\sigma_{t}$ :

$$
\varepsilon_{t}=\sigma_{t} z_{t}
$$

R.F. Engle [1982] zaproponował, aby wariancja była w tym wypadku modelowana jako warunkowa względem przeszłych obserwacji przy użyciu modelu 
autoregresyjnej heteroskedastyczności warunkowej (autoregressive conditional heteroscedasticity - ARCH). Najprostszą jego postacią jest:

$$
\sigma_{t}^{2}=\alpha+\beta \varepsilon_{t-1}^{2}, \quad \alpha>0, \beta \geq 0 .
$$

Włączając opóźnioną wartość $\sigma_{t}^{2}$, otrzymujemy z kolei najprostszą postać uogólnionego modelu ARCH określanego jako GARCH(1,1) (generalized autoregressive conditional heteroscedasticity) (zob. [Bollerslev 1986, Taylor 1986]):

$$
\sigma_{t}^{2}=\alpha+\beta_{1} \varepsilon_{t-1}^{2}+\gamma_{1} \sigma_{t-1}^{2},
$$

gdzie dodatkowo $\gamma_{i} \geq 0$.

Na podstawie przeprowadzonych wcześniej przez autora badań (zob. [Węgrzyn 2013]), można stwierdzić, że w odniesieniu do indeksu WIG20, ale nie tylko, postać modelu AR(1)-GARCH(1,1) z rozkładem błędu $t$-Studenta jest postacią o dobrym dopasowaniu. Wybór takiego modelu jest także zgodny z wynikami badań spotykanymi w literaturze (zob. [Doman i Doman 2009, s. 98-103; Osiewalski, Pajor i Pipień 2004, s. 17-39]).

Po wyliczeniu logarytmicznych stóp zwrotu dla poszczególnych indeksów przeprowadzono zatem oszacowania parametrów modelu metodą największej wiarygodności dla wyodrębnionego wcześniej okresu 2 i 4. Obliczeń dokonano za pomocą programu komputerowego Time Series Modelling.

Przykładowe wyniki oszacowań parametrów modeli zostały zawarte w tabeli 6 . Na podstawie wszystkich wyników zauważono, że, poza parametrem modelu $\operatorname{AR}(1)-a_{1}$, który rzadko wykazywał istotność statystyczną, pozostałe parametry wykazały istotność statystyczną w przypadku każdego z analizowanych indeksów.

Na podstawie parametrów modeli $\operatorname{GARCH}(1,1)$ stwierdzono następnie, że w każdym przypadku suma parametrów $\beta_{1}$ i $\gamma_{1}$ była mniejsza od jeden, co oznacza, że proces $\varepsilon_{t}$ generowany przez $\operatorname{GARCH}(1,1)$ jest kowariancyjnie stacjonarny. W takiej sytuacji wariancja procesu $\varepsilon_{t}$ jest równa [Doman i Doman 2009, s. 83]:

$$
E\left(\varepsilon_{t}^{2}\right)=\frac{\alpha}{1-\beta_{1}-\gamma_{1}} .
$$

Posługując się tą formułą, obliczono wariancje procesu dla poszczególnych indeksów w okresie 2 oraz 4, a następnie przedstawiono je po przeliczeniu na odchylenia standardowe w ujęciu rocznym w tabeli 7.

Na podstawie poziomów odchyleń standardowych w ujęciu rocznym można stwierdzić wzrost zmienności w okresie 4 w odniesieniu do okresu 2 w 11 przypadkach na 15 (ok. 73\%). Tylko w przypadku indeksów NASDAQ, WIG20, Nikkei225 i Bovespa nastąpił spadek. Odchylenia standardowe w ujęciu rocznym w okresie 2 ukształtowały się w przedziale $27-80 \%$, a w okresie 4 - w przedziale 40,5-275,5\%. Największy wzrost odchyleń standardowych nastąpił w przypadku indeksów Shanghai, RTS oraz FTSE250. 
Tabela 6. Przykładowe wyniki oszacowania parametrów modeli dla okresu 2

\begin{tabular}{|c|c|c|c|}
\hline Parametr & Ocena parametru & Błąd standardowy & Wartość $p$ \\
\hline \multicolumn{5}{|c|}{ Parametry modelu dla indeksu SENSEX } \\
\hline$a_{1}$ & 0,11378 & 0,03078 & 0,000 \\
\hline$\sqrt{\alpha}$ & 0,68912 & 0,0718 & - \\
\hline$\beta_{1}$ & 0,12995 & 0,02781 & 0,000 \\
\hline$\gamma_{1}$ & 0,82285 & 0,03461 & 0,000 \\
\hline$\sqrt{D F}$ & 3,6282 & 0,5729 & - \\
\hline \multicolumn{5}{|c|}{ Parametry modelu dla indeksu Bovespa } \\
\hline$a_{1}$ & 0,0185 & 0,02884 & 0,521 \\
\hline$\sqrt{\alpha}$ & 1,18296 & 0,1076 & 0,000 \\
\hline$\beta_{1}$ & 0,04541 & 0,01213 & 0,000 \\
\hline$\gamma_{1}$ & 0,89953 & 0,02233 & - \\
\hline$\sqrt{D F}$ & 4,141 & 0,9949 & 0,000 \\
\hline \multicolumn{5}{|c|}{ Parametry modelu dla indeksu IPC } \\
\hline$a_{1}$ & 0,10773 & 0,02872 & - \\
\hline$\sqrt{\alpha}$ & 0,70973 & 0,0616 & 0,000 \\
\hline$\beta_{1}$ & 0,08732 & 0,01769 & 0,000 \\
\hline$\gamma_{1}$ & 0,84616 & 0,02832 & - \\
\hline$\sqrt{D F}$ & 3,20329 & 0,4998 & \\
\hline
\end{tabular}

Objaśnienia: $\sqrt{D F}$ - pierwiastek oszacowanej liczby stopni swobody (degree of freedom) dla rozkładu $t$-Studenta.

Źródło: obliczenia własne za pomocą programu Time Series Modelling 4.31.

Pytanie o trwałość wzrostu zmienności jest, jak się wydaje, przedwczesne. Wzrost zmienności może wynikać bowiem z trwałych przyczyn, o których była mowa w poprzedniej części, ale może też być skutkiem opóźnionych reakcji na niezażegnany jeszcze do końca kryzys finansowy. Kiedy nie będzie już widocznych skutków kryzysu, wyniki tego typu analizy będzie można zinterpretować bardziej jednoznacznie.

Uzyskane wyniki dotyczące siły powiązań oraz zmienności warto odnieść do wyników tego rodzaju badań spotykanych w innych publikacjach. Do jednych z pierwszych prac dotyczących pomiaru siły powiązań między rynkami finansowymi można zaliczyć [Levy i Sarnat 1970] i [Solnik 1974]. Autorzy badali w nich korelacje pomiędzy poszczególnymi rynkami w celu oceny możliwości dywersyfikacji portfela międzynarodowego. Kolejnym etapem było zaangażowanie do tego typu badań wielowymiarowych modeli GARCH i wielowymiarowych modeli 
zmienności stochastycznej, a następnie przełącznikowego modelu GARCH z przełączaniem typu Markowa.

Tabela. 7. Oszacowane odchylenia standardowe dla okresu 2 i 4

\begin{tabular}{|l|c|c|}
\hline \multirow{2}{*}{ Indeks } & \multicolumn{2}{|c|}{ Odchylenie standardowe procesu w ujęciu rocznym } \\
\cline { 2 - 3 } & okres 2 & okres 4 \\
\hline DJIA & 39,8558 & 42,6694 \\
\hline NASDAQ & 64,2697 & 52,0880 \\
\hline TSX & 37,7096 & 40,4681 \\
\hline FTSE250 & 27,0350 & 52,2546 \\
\hline CAC40 & 47,0401 & 67,3083 \\
\hline DAX & 59,1744 & 68,1903 \\
\hline RTS & 67,5174 & 100,8963 \\
\hline WIG20 & 76,7145 & 67,5893 \\
\hline Nikkei225 & 69,1655 & 57,2264 \\
\hline Shanghai & 78,2406 & 275,5957 \\
\hline Hang Seng & 69,7167 & 70,9392 \\
\hline All Ordinaries & 41,9592 & 46,7718 \\
\hline SENSEX & 50,1526 & 68,9299 \\
\hline Bovespa & 79,7117 & 63,7920 \\
\hline IPC & 43,5098 & 49,7692 \\
\hline
\end{tabular}

Źródło: obliczenia własne.

Na podstawie prowadzonych badań w wielu pracach stwierdzano, że siła powiązań rynków finansowych rośnie, gdy występują ujemne stopy zwrotów lub wzrasta zmienność (zob. np. [Longin i Solnik 2001, Ang i Bekaert 2002, Capiello, Engle i Sheppard 2006]). Oznaczało to łączenie wzrostu siły powiązań z sytuacjami kryzysowymi.

Z drugiej strony natomiast na przykład G. Bekaert, R.J. Hodrick i X. Zhang [2005] uznali, że nie ma żadnych dowodów na tendencję wzrostową korelacji stóp zwrotów, oprócz europejskich giełd papierów wartościowych. M. Glaser i S. Schaarschmidt [2012] rozszerzyli tę analizę, wskazując, że współzależności (comovements) są napędzane przez spółki o dużej kapitalizacji. Uznali oni, że nawet bez europejskiej integracji rynkowej doszłoby do wzrostu korelacji stóp zwrotów spółek o dużej kapitalizacji.

Z kolei D.W. Blackburn i N.K. Chidambaran [2011] wskazali na dwa zasadnicze aspekty badania zmian współzależności. Po pierwsze, miary współzależności określanych za pomocą modeli stóp zwrotu są uwarunkowane wyborem modelu. 
Ponieważ miary są zależne od modeli, niestwierdzenie zmian we współzależnościach może być wynikiem źle określonego modelu. Po drugie, musi być wyraźne oczekiwanie co do przyczyn zmian współzależności, aby postawić rozsądne hipotezy i wybrać odpowiednie statystyki testowe do zbadania tendencji. W ich ocenie przeprowadzone przez nich badania zawierały zarówno nową metodykę wolną od obciążeń, jak i nowsze testy tendencji. Po zbadaniu współzależności rynków giełdowych 23 krajów rozwiniętych i 10 krajów wschodzących w latach 19802010 uznali oni, że współzależności stóp zwrotów spółek wzrastały znacznie od połowy lat 90 . XX w. do $2010 \mathrm{r}$. tak na rynkach rozwiniętych, jak i wschodzących. Wywnioskowali oni, że współzależności dramatycznie zmieniły się i światowe giełdy papierów wartościowych są teraz coraz bardziej zintegrowane. Wskazali oni także, że światowe współzależności są napędzane przez międzynarodowe przepływy inwestycyjne.

Szerzej na przyczyny wysokich współczynników korelacji pomiędzy indeksami giełdowymi poszczególnych krajów spojrzeli J. Friedman i Y. Shachmurove [2005]. Zaliczyli oni do nich: wzrost powiązań gospodarczych pomiędzy państwami, zniesienie ograniczeń w przepływie kapitału, dóbr i usług oraz postęp technologii komunikacyjnej, która powoduje natychmiastowy przepływ informacji pomiędzy rynkami finansowymi.

W ostatnich latach coraz większego znaczenia nabierają prace, w których tego rodzaju zależności opisywane są za pomocą kopuli. W pracy [Chen i Poon 2007] autorzy przeanalizowali za ich pomocą następstwa kryzysu azjatyckiego i innych zdarzeń rynkowych i stwierdzili, że od kryzysu azjatyckiego zależność pomiędzy rynkami wzrosła. Zaobserwowali także, że rozwinięte rynki finansowe są najbardziej podatne na kryzys finansowy i tzw. zarażanie, a rynki Ameryki Łacińskiej są niemal odizolowane od wszystkich zdarzeń ekstremalnych. Wzrost zależności został również ogólnie zaobserwowany w pracach [Bartram, Taylor i Wang 2007] oraz [Poon, Rockinger i Tawn 2004].

W pracy [Doman i Doman 2014, s. 92-114] przeprowadzono zaawansowaną metodologicznie analizę 16 par indeksów giełdowych w okresie 1995-2009, wyodrębniając różne podokresy równej długości. Opisu dynamiki zależności dokonano za pomocą modeli kopuli z przełączaniem typu Markowa. Badano zależność „uśrednioną”, opisywaną za pomocą warunkowego współczynnika rho Spearmana, oraz zależność pomiędzy wartościami ekstremalnymi za pomocą współczynników zależności w ogonach rozkładów warunkowych. W przypadku długich podokresów (4-7 lat) zaobserwowano systematyczny i istotny statystycznie wzrost średniej siły powiązań interpretowany jako wynik postępującej globalizacji. Nie stwierdzono natomiast wzrostu zależności pomiędzy zwrotami ekstremalnymi. Formułowana często w literaturze teza o wzroście siły powiązań pomiędzy rynkami w okresach kryzysów nie została zatem potwierdzona, przy 
czym w badaniu tym żaden z rozważanych podokresów nie odpowiadał w całości okresowi kryzysu, co mogło wpłynąć na ostateczny wynik.

Ten krótki przegląd wyników badań wskazuje, że wyniki te nie zawsze są jednoznaczne. Zależy to oczywiście od stosowanych metod pomiaru, badanych okresów czy chociażby sposobu synchronizacji danych. Pojawia się jednak coraz więcej nowych opracowań wskazujących, że taka istotna tendencja wzrostu siły powiązań występuje. Zaprezentowane przez autora wyniki badań wpisują się właśnie w ten nurt. Mimo że pod względem metodologicznym przedstawione badania nie są szczególnie zaawansowane, to obejmują one celowo dobrane podokresy uwzględniające określone sytuacje na rynkach finansowych, w tym lata 2010-2013.

\section{Zakończenie}

Mimo że uzyskane wyniki mogą być obarczone błędem wynikającym z wybranych okresów porównań czy zbyt krótkiego ostatniego okresu względnej stabilizacji, warto zwrócić uwagę, iż procesy powiązane z postępującą globalizacją gospodarki światowej stanowią pewnego rodzaju wyzwanie dla zapewnienia odpowiedniego poziomu bezpieczeństwa na rynkach finansowych. Globalizacja doprowadziła bowiem do tego, że kryzysy finansowe nie dotykają pojedynczych gospodarek, lecz nabierają wymiaru międzynarodowego. Wzrost korelacji stóp zwrotu oznacza dla międzynarodowych inwestorów zmniejszenie efektu ograniczenia ryzyka wynikającego z dywersyfikacji portfela. Obecnie wielu autorów wskazuje już na potrzebę międzynarodowej dywersyfikacji na podstawie sektorów, a nie krajów. Ograniczenie efektów dywersyfikacji może prowadzić także do wzrostu zainteresowania instrumentami pochodnymi, które dawałyby możliwość ograniczania ryzyka, ale jednocześnie nie stanowiły zagrożenia dla stabilności rynków finansowych. Wzrastająca współzależność rynków giełdowych oznacza zatem poważne wyzwania zarówno dla nauki, jak i praktyki.

Jak zauważono wcześniej, poziom zmienności może odgrywać ważną rolę w kształtowaniu się współczynników korelacji stóp zwrotu indeksów giełdowych. Stąd oparta na modelach GARCH pogłębiona analiza zmian w zmienności indeksów giełdowych, która potwierdziła w ponad $70 \%$ przypadków wzrost zmienności na analizowanych rynkach, miała w tym wypadku istotne znaczenie przy formułowaniu ostatecznych wniosków. Uzyskane wyniki wskazały także na potrzebę dalszych badań w tym zakresie. 


\section{Literatura}

Ang A., Bekaert G. [2002], International Asset Allocation with Regime Shifts, „Review of Financial Studies", vol. 15.

Bartram S.M., Taylor S.J., Wang Y.-H. [2007], The Euro and European Financial Market Integration, ,Journal of Banking and Finance”, vol. 31(5).

Bekaert G., Hodrick R.J., Zhang X. [2005], International Stock Return Comovments, NBER Working Papers, nr 11906.

Blackburn D.W., Chidambaran N.K. [2011], Is World Stock Market Co-movement Changing? November 15, http://ssrn.com/abstract=2024770.

Bollerslev T. [1986], Generalized Autoregressive Conditional Heteroscedasticity, „Journal of Econometrics", vol. 31.

Capiello L., Engle R.F., Sheppard K. [2006], Asymmetric Dynamics in the Correlations of Global Equity and Bond Returns, ,Journal of Financial Econometrics”, vol. 4, http:// dx.doi.org/10.1093/jjfinec/nbl005.

Chen S., Poon S.-H. [2007], Modelling International Stock Market Contagion Using Copula and Risk Appetite, MBS Working Paper Series, http://ssrn.com/ abstract=1024288.

Doman M., Doman R. [2009], Modelowanie zmienności i ryzyka. Metody ekonometrii finansowej, Wolters Kluwer, Kraków.

Doman M., Doman R. [2014], Dynamika zależności na globalnym rynku finansowym, Difin, Warszawa.

Engle R.F. [1982], Autoregressive Conditional Heteroscedasticity with Estimates of the Variance of UK Inflation, „Econometrica”, vol. 50, http://dx.doi.org/10.2307/1912773.

Friedman J., Shachmurove Y. [2005], European Stock Markets Dynamics before and after the Introduction of the Euro, PIER, Working Paper, $\mathrm{nr} 28$.

Glaser M., Schaarschmidt S. [2012], Market Integration and Small Stock Returns: A Co-movement Analysis, October 30, http://ssrn.com/abstract=2021195.

Kowalak T. [2006], Integracja rynków kapitałowych w Unii Europejskiej, Twigger, Warszawa.

Levy H., Sarnat M. [1970], International Diversification of Investment Portfolios, „American Economic Review", vol. 60.

Longin F., Solnik B. [2001], Extreme Correlation of International Equity Markets, ,Journal of Finance", vol. 56, http://dx.doi.org/10.1111/0022-1082.00340.

Mrzygłód U. [2011], Procesy integracyjne na rynkach kapitałowych Unii Europejskiej, Materiały i Studia NBP, nr 257.

Osiewalski J., Pajor A., Pipień M. [2004], Bayesowskie modelowanie i prognozowanie indeksu WIG z wykorzystaniem procesów GARCH i SV [w:] XX Seminarium Ekonometryczne im. Prof.Zbigniewa Pawłowskiego, red. A. Zeliaś, Akademia Ekonomiczna w Krakowie, Kraków.

Poon S.-H., Rockinger M., Tawn J. [2004], ExtremeValue Dependence in Financial Markets: Diagnostics, Models and Financial Implications, ,Review of Financial Studies”, vol. 17(2).

Solnik B.H. [1974], Why Not Diversify Internationally Rather than Domestically? „Financial Analyst Journal", vol. 30, http://dx.doi.org/10.2469/faj.v30.n4.48.

Taylor S.J. [1986], Modelling Financial Time Series, J. Wiley, Chichester. 
Węgrzyn R. [2013], Zastosowanie wybranych modeli zmienności w analizie ryzyka cen akcji [w:] Zarzqdzanie finansami. Wycena przedsiębiorstw, zarzqdzanie wartościq, zarzqdzanie ryzykiem, red. D. Zarzecki, Zeszyty Naukowe Uniwersytetu Szczecińskiego. Finanse, rynki finansowe, ubezpieczenia, nr 761(60).

\section{Changes in the Strength of Connections and the Volatility of Indices of the World Stock Exchanges}

The aim of the study is to identify and assess the changes in the evolution of stock market indices, paying particular attention to changes in the strength of connections of indices representing the shares of companies from different geographic regions and countries, as well as changes in the volatility of these indices. The analysis involves a comparison of how the indices have shaped up over time, isolating sub-periods and determining changes in the strength of connections between different indices. A depth analysis of changes in the volatility of indices was based on the estimated GARCH models. The analysis included a total of 15 stock market indices in the period 2.01.2000-31.10.2013. On the basis of the empirical results it may be concluded that, in spite of periodic fluctuations in the level of correlation coefficients, the vast majority of them grew in the long term. In over the $70 \%$ of cases volatility grew on the analysed markets.

Keywords: stock market indices, correlation, volatility, world stock exchanges. 